\title{
ACKNOWLEDGMENTS FOR THIS EDITION
}

Just as the first edition of this guide was the work of many people, so too this revised edition is the reflection of many naturalists, biologists, and other specialists who generously donated their time and expertise in reviewing and reshaping the text. This was not in every case an easy task because some fields of study have grown immensely in complexity since Storer and Usinger first published their book in 1963. Even more astonishing, some groups of plants and animals have received so little attention that it's nearly impossible to gather information for a book of this nature. Lichens and quite a number of invertebrates come to mind, but it's surprising how little is known about the status and distribution of charismatic groups like amphibians, reptiles, birds, and mammals.

I wish to thank the folks who helped bring this text up-to-date, taking time to offer feedback and enduring countless questions because, in many cases, they wanted to contribute to a book that affected each of their own lives in some way.

INTRODUCTION: Michael Barbour (Plant and Animal Distribution), Steve Beckwitt (The Changing Landscape), Bob Erickson (The Changing Landscape), Mary Hill (Geological History), King Huber (Geological History), and Randall Osterhuber (Climate).

FUNal: Dennis E. Desjardin, Daniel A. Nicholson, Margriet Wetherwax, and Michael Wood.

LICHENS: Charis Bratt and Stephen Sharnoff.

MOSSES: Brent Mishler and Jim Shevock.

FERNS: Alan R. Smith and Margriet Wetherwax.

flowering PLANTS: Julie Stauffer Carville, Carolyn Chainey-Davis, and Margriet Wetherwax.

SHRUBS: Hugh N. Mozingo, John Stuart, and Margriet Wetherwax.

TREES: Ronald M. Lanner, Bruce M. Pavlik, and Margriet Wetherwax.

miscellaneous ANimals: Elizabeth Kools (overall review), D. Christopher Rogers (overall review), Darrell Ubick (spiders and relatives), Leonard S. Vincent (overall review), and Gary C. Williams (overall review).

INSECTS: Lawrence A. Baptiste (overall review), Kathy R. Biggs (dragonflies and damselflies), Michael M. Collins (moths and overall review), Steve Heydon (overall review), Tim Manolis (dragonflies and damselflies), Paul A. Opler (butterflies), Jerry A. Powell (overall review), D. Christopher Rogers (overall review), and Arthur Shapiro (butterflies).

FISH: Peter B. Moyle.

AMPHIBIANS AND REPTILES: Sean Barry, Gary M. Fellers, Robert Hansen, and Mark R. Jennings. 
BIRDS: Edward C. Beedy, David F. DeSante, Ned K. Johnson, and Mac McCormick.

mammals: Peter E. Busher, John H. Harris, E. W. Jameson, Jr., and James L. Patton.

Special thanks to Bruce M. Pavlik and Joseph L. Medeiros for extensive comments on the original Storer and Usinger text, and to Simone Whitecloud for assistance in reviewing drafts of the revised text.

David Lukas also thanks the many people who have joined him in exploring the Sierra, with deep gratitude to Eric Beckwitt, Tavia Cathcart, the late Chuck Dockham, Bob Erickson, Liese Greensfelder, Sara Greensfelder, Maya Hill, Theo Killigrew, Carole Koda, Erin Noel, Gary Snyder, and Jerry Tecklin for their unique and instructive ways of making the Sierra Nevada home. Thanks also go to Brett Hall Jones (Squaw Valley Community of Writers), Jack Hicks (Art of the Wild), Bartshe Miller (Mono Lake Committee), and Jim Steele (Sierra Nevada Field Campus), for each providing a special place to teach Sierra Nevada natural history.

This revision would not have been possible without the hard work of the folks at University of California Press, especially Laura Cerruti, who got the ball rolling. Laurel Anderson, Cindy Wathen, and Stephanie Rubin did a tremendous job in art research; Joanne Bowser at TechBooks carefully finetuned the manuscript; and Scott Norton skillfully and graciously brought all the pieces together.

David Lukas 